\title{
PENGARUH MODEL PEMBELAJARAN PICTURE AND PICTURE TERHADAP KEMAMPUAN MENULIS NASKAH DRAMA SATU BABAK
}

\author{
Epitamala Nainggolan ${ }^{1}$, Petrus Purwanto ${ }^{1}$, dan Ermina Waruwu ${ }^{1}$ \\ ${ }^{1}$ Universitas Prima Indonesia (UNPRI) Medan \\ Email: evitanainggolan1997@gmail.com
}

\begin{abstract}
Abstrak
Penelitian ini bertujuan untuk mengetahui pengaruh model pembelajaran picture and picture terhadap menulis naskah drama pada siswa kelas VIII. Model picture and picture merupakan model yang dapat mendorong siswa lebih kreatif dan aktif dalam proses pembelajaran. Metode yang digunakan adalah metode eksperimen, dengan model post-test only control design. Pengolahan data diperoleh hasil post-test kelas kontrol dengan nilai rata-rata 75,833 standar deviasi 8,461, standar error 1,562 dan kelas eksperimen nilai rata-rata 82,66, standar deviasi 6,914 standar error 1,284. Hasil perhitungan normalitas kelas kontrol memperoleh harga $\mathrm{L}_{\text {hitung }}<\mathrm{L}_{\text {tabel }}$ sebesar $0,1321<$ 0,1617dan kelas eksperimen memperoleh harga $\mathrm{L}_{\text {hitung }}<\mathrm{L}_{\text {tabel }}$ sebesar 0,1446<0,1617. Ini membuktikan bahwa kedua data tersebut berdistribusi normal. Hasil perhitungan homogenitas memperoleh harga $\mathrm{L}_{\text {hitung }}<\mathrm{L}_{\text {tabel }}$ sebesar $1,481<1,858$. Hal ini membuktikan sampel berasal dari populasi yang homogen. Hasil perhitungan hipotesis memperolah harga $\mathrm{T}_{\text {hitung }}>\mathrm{T}_{\text {tabel }}$ sebesar 3,531>2,002, maka hipotesis nihil $\left(\mathrm{H}_{0}\right)$ ditolak dan hipotesis alternatif $\left(\mathrm{H}_{\mathrm{a}}\right)$ diterima. Diperoleh kesimpulan terdapat pengaruh yang signifikan dengan penggunaan model pembelajaran picture and picture terhadap kemampuan menulis naskah drama satu babak pada siswa kelas VIII tahun pembelajaran 2018/2019.
\end{abstract}

Kata kunci: Picture and Picture, Naskah Drama

\begin{abstract}
This study aims to determine the effect of the picture and picture learning model on writing a one-round drama script in class VIII Imelda Middle School in Medan. Picture and picture learning model is a model that can encourage students to be more creative and active in the learning process. The research method used was the experimental method, with a post-test only control design model. Data processing obtained the results of the control class post-test with an average value (mean) of 75,833 standard deviations 8,461, standard error 1,562 and the experimental class mean (mean) 82,66, standard deviation 6,914 standard error 1,284. The results of the calculation of the control class normality obtain the Lhitung price <Ltable of $0.1321<0.1617$ and the experimental class gets the Lhitung price <Ltable of $0.1446<0.1617$. This proves that the two data are normally distributed. The homogeneity calculation results obtained the Lhitung price <Ltable of $1.481<1.858$. This proves the sample comes from a homogeneous population. The results of the calculation of the hypothesis obtain the price of Calculate> T table of 3.531> 2.002, then the null hypothesis $(\mathrm{HO})$ is rejected and the alternative hypothesis $(\mathrm{Ha})$ is accepted. Thus, it can be concluded that there is a significant influence with the use of the picture and picture learning model on the ability to write a one-round drama script on the eighth grade students of Medan Imelda Middle School in the 2018/2019 learning year.
\end{abstract}

Keywords: Picture and Picture, Drama Manuscript

\section{PENDAHULUAN}


Menulis merupakan salah satu aspek dari keterampilan berbahasa. Dalman (2012: 3), Mengemukakan bahwa "Menulis merupakan suatu kegiatan komunikasi berupa penyampaian pesan (informasi) secara tertulis kepada pihak lain dengan menggunakan bahasa tulis sebagai alat atau medianya. Dengan menulis peserta didik mampu menuangkan ide kreatifnya dalam bentuk bahasa tulis dalam tujuan memberitahu, meyakinkan atau menghibur.

Menulis drama termasuk kompetensi dasar yang harus dicapai oleh siswa dalam pembelajaran Bahasa Indonesia. Kompetensi ini terdapat dalam kurikulum 2013 pada semester genap, yaitu KD 4.16. Menulis drama dengan memperhatikan unsur pembangunnya. Dalam hal ini pemerintah mengharapkan siswa mampu menulis drama dengan baik yakni memperhatikan unsur pembangun drama.

Ada beberapa hal yang menyebabkan rendahnya kemampuan peserta didik dalam kemampuan menulis naskah drama, diantaranya adalah kurangnya antusias siswa dalam menulis naskah drama. Banyak peserta didik yang merasa kurang tertarik dengan kegiatan menulis. Hal ini sering terjadi karena kurangnya motivasi dari dalam diri siswa. Disisi lain siswa kurang berani dalam mencoba yang artinya mereka takut untuk gagal dan sering merasa malu dan takut hasil tulisannya akan ditertawakan oleh temannya. Namun rasa percaya diri seseorang juga sangat berpengaruh terhadap suatu karya. Dimana, diketahui bahwa peserta didik kurang memiliki rasa percaya diri yang tinggi dikarenakan peserta didik tidak memahami cara menulis naskah drama.

Selain beberapa hal diatas model pembelajaran yang digunakan masih konvensional. Dikatakan konvensional karena guru tidak memberikan kesempatan kepada siswa untuk lebih aktif dalam pembelajaran. Artinya, guru lebih banyak menghabiskan waktu dengan ceramah. Cara mengajar guru yang kurang menyenangkan itu juga sangat berpengaruh kepada nilai siswa ketika guru menggunakan model pembelajaran yang efektif akan memperbesar kemungkinan hasil belajar siswa dapat meningkat. Artinya dalam masalah ini, guru diharapkan melaksanakan pembelajaran dengan cara mengajar yang inovatif.

Seorang pendidik harus mampu melakukan yang terbaik dalam meminimalisasi kesenjangan yang akan dihadapi oleh pendidik. Dalam hal ini pendidik harus mampu membuat hasil pembelajaran meningkat dan lebih baik lagi. Untuk mencapai hasil yang diharapkan, guru harus mampu membuat pembelajaran lebih aktif, kreatif, inovatif, menyenangkan, tanpa melupakan tujuan pembelajaran serta ketuntasan harus dicapai oleh siswa. Misalnya, guru menggunakan pembelajaran, metode pembelajaran, strategi pembelajaran serta media, dan tehnik pembelajaran yang sesuai dengan materi pembelajaran.

Adapun alasan peneliti menawarkan model ini adalah karena model ini memiliki kelebihan yang cukup baik. Misalnya, dalam model ini guru memerintahkan siswa agar mampu bekerja sama dengan teman satu kelompoknya terhadap gambar yang ditunjukkan oleh guru. Melalui gambar yang ditunjukkan oleh guru siswa akan mampu mengolah kata dan akan dituliskan dalam lembar kerja siswa. Maka siswa akan mampu memahami pembelajaran lebih baik lagi, sehingga nilai ketuntasan siswa meningkat. Pembelajaran juga akan lebih berkesan sebab siswa dapat secara langsung mengamati gambar yang telah dipersiapkan oleh guru. Dalam penggunakan metode pembelajaran ini, maka pembelajaran akan lebih menarik, sebab gambar dapat meningkatkan perhatian anak untuk mengikuti proses belajar mengajar.

Berdasarkan pemaparan di atas, maka peneliti tertarik untuk membahas judul penelitian "Pengaruh Model Pembelajaran Picture and Picture Terhadap Kemampuan Menulis Naskah Drama Satu Babak Siswa Kelas VIII SMP Swasta Imelda Medan Tahun Pelajaran 2018/2019.

Model picture and picture adalah suatu model belajar menggunakan berbagai jenis gambar yang menarik perhatian siswa yang dipasangkan atau diurutkan langsung oleh siswa itu sendiri dan menjadi urutan gambar yang sempurna. Dengan demikian model pembelajaran ini menggunakan gambar sebagai media utamanya dalam proses pembelajaran. Gambar-gambar yang digunakan sebagai media inilah yang berperan penting dalam proses pembelajaran. Sehingga seorang guru harus 
mempersiapkan gambar-gambar yang akan digunakan sebelum proses pembelajaran berlangsung, gambar-gambar ini nantinya dapat disajikan dalam bentuk kartu dan bentuk lainnya sesuai inovasi guru.

\section{Picture and Picture}

Menurut Shohimin (2016 :122) Model picture and picture adalah suatu model pembelajaran menggunakan gambar yang dipasangkan atau diurutkan menjadi urutan logis. Model pembelajaran ini mengadalkan gambar yang menjadi faktor utama dalam proses pembelajaran. Maka dari itu, sebelumnya guru menyiapkan gambar yang akan ditampilkan, baik dalam bentuk kartu atau carta dalam ukuran besar.

Fathurrohman (2018:169) picture and picture berbeda dengan media gambar dimana picture and picture berupa gambar yang belum disusun secara berurutan yang menggunakannya adalah siswa, sedangkan media gambar berupa gambar utuh yang digunakan oleh guru dalam proses pembelajaran.

Model apapun yang digunakan selalu menekankan keaktifan peserta didik dalam setiap proses pembelajaran. Cirinya adalah inovatif dan kreatif. Inovatif artinya setiap pembelajaran harus memberikan sesuatu yang baru, berbeda, dan selalu menarik minat peserta didik. Sementara kreatif artiya setiap pembelajaran harus menimbulkan minat kepada peserta didik untuk menghasilkan sesuatu atau dapat menyelesaikan suatu masalah dengan menggunakan metode, teknik, atau cara yang dikuasai oleh mereka yang diperoleh dari proses pembelajaran.

\section{Menulis}

Menurut Dalman (2012:4) 'Kemampuan menulis merupakan sebagai kegiatan merangkai huruf menjadi kata atau kalimat untuk disampaikan kepada orang lain, sehingga orang lain dapat memahaminya. Dalam hal ini, dapat terjadinya komunikasi antara penulis dan pembaca dengan baik'. Menurut Tarigan (Dalman 2012 :4) 'Menulis merupakan sebuah proses kreatif menuangkan gagasan dalam bentuk bahasa tulis dalam tujuannya misalnya memberitahu, meyakinkan atau menghibur'. Dengan demikian, keterampilan menulis merupakan salah satu cara seseorang untuk mengembangkan kemampuan yang dimilikinya untuk dapat melakukan suatu proses kegiatan menulis untuk mengungkapkan suatu ide/gagasan, perasaan, pendapat, dan situasi seseorang serta mengekspresikan perasaan dengan menggunakan bahasa tulisan. Menulis dapat diartikan sebagai suatu alat untuk menyampaikan informasi melalui ide/gagasan yang disusun sesuai dengan kebutuhan-kebutuhan pembaca sekaligus menjadi sumber utama terciptanya kreativitas seseorang.

\section{Drama}

Drama adalah suatu karangan dalam prosa atau narasi atau juga puisi yang menyajikan dalam dialog atau pantonim atau cerita yang mengandung konflik atau kontras seorang tokoh Tarigan (Addin 2009 :9) 'Hal yang pertama yang terlintas di pikiran kita saat berhadapaan dengan drama ialah sebuah adengan atau tontonan dan pertunjukan yang membawa suatu cerita atau kisah'. Pembahasan dalam penelitian ini adalah pengertian drama, ciri-ciri, unsur-unsur drama, menulis naskah drama.

Menurut Addin (2009:19) Sebagai suatu karya sastra, drama memiliki unsur-unsur pembangun. Unsur-unsur tersebut dibagi atas dua jenis yaitu unsur intrinsik dan ekstrinsik. Unsur intrinsik adalah unsur pembangun yang berasal dari dalam karya sastra tersebut. Artinya unsur ini merupakan suatu sistematika yang berhubungan satu dengan yang lainnya dan menjadi satu dan membentuk suatu karya sastra.

Selanjutnya, Suryadi (2013 :5-6) menyebutkan bahwa Drama ialah sebuah karya fiksi atau rekaan yang mementingkan dialog dan perwatakan. Sebuah drama yang lengkap ditulis dinamakan naskah. Drama yang telah bertulis (naskah) itu masih tidak lengkap jika tidak di pentaskan. Jadi, drama ditulis untuk dibaca dan dipentaskan. 
Sedangkan naskah drama satu babak dapat diberi batasan sebagai salah satu jenis karya sastra yang ditulis dalam bentuk dialog yang didasarkan atas konflik dan memiliki satu tempat untuk beradegan. Babak diartikan sebagai bagian besar dalam suatu drama atau lakon (terdiri dari beberapa adegan), atau diartikan juga sebagai bagian dari keseluruhan proses, kejadian, atau peristiwa. Ciriciri naskah drama satu babak Drama satu babak mempunyai karekter yang lebih sedikit dan mungkin latar yang lebih sederhada. Biasanya, drama satu babak hanya berfokus pada karakter utama dan satu tujuan. Sementara waktu untuk sub-alur dan adengan yang tidak melibatkan karakter utama, kisahnya hanya sedikit. Inilah yang harus anda perhatikan saat membaca drama satu babak, dan sesuatu yang perlu diingat saat anda masuk kedalam proses menulis.

Hipotesis yang ditegakkan oleh peneliti adalah hipotesis alternatif $\left(\mathrm{H}_{\mathrm{a}}\right)$ yang berbunyi "ada pengaruh model picture and picture terhadap kemampuan menulis naskah drama satu babak oleh siswa kelas VIII SMP Swasta Imelda Medan Tahun Pelajaran 2018/2019”

\section{METODE}

Pendekatan yang digunakan dalam penelitian ini pendekatan kuantitatif dalam suatu penelitian, metode memegang peranan yang sangat penting. hal ini disebabkan karena semua kegiatan yang dilakukan dalam penelitian dipengaruhi oleh metode yang digunakan.

Sesuai dengan pendapat Arikunto (2010 :203) "Menyatakan bahwa metode penelitian merupakan struktur yang sangat penting, karena berhasil tidaknya ataupun tinggi rendahnya suatu kualitas hasil penelitian ditentukan oleh ketepatan dalam memilih metode penelitian”. Sesuai dengan masalah dan tujuan penelitian maka metode yang digunakan dalam penelitian ini adalah metode eksperimen dengan tujuan ingin mengetahui pengaruh model pembelajaran picture and picture terhadap kemampuan menulis naskah drama satu babak di SMP Imelda Medan Tahun Pelajaran 2018/2019.

Adapun metode yang digunakan dalam penelitian ini adalah metode eksperimen (True Experimental Design) dengan model posttest-only control design (Sugiyono 2017 :75) dikatakan True Experimental karena dalam desain ini, peneliti dapat mengontrol semua variabel luar yang mempengaruhi jalannya eksperimen.

Menurut Sugiyono (2017:80), "Populasi adalah wilayah generalisasi yang terdiri dari objek/subjek yang mempunyai kualitas dan karasteristik tertentu yang ditetapkan oleh peneliti untuk dipelajari dan kemudian ditarik kesimpulannya.

Berdasarkan teori di atas, populasi dalam penelitian ini adalah keseluruhan siswakelas VIII SMP Imelda Medan Tahun Pelajaran 2018/2019 yang berjumlah 161 orang. Populasi penelitian ini ada lima kelas. Dalam penelitian ini peneliti memilih probality sampling dengan jenis sampel simple random sampling. Dikatakan simple (sederhana) karena pengambilan anggota sampel dari populasi dilakukan secara acak tanpa memperhatikan strata yang ada dalam populasi itu, maka sampel dalam penelitian ini ialah kelas VIII-B dan kelas VIII-C di mana kelas VIII-B adalah kelas kontrol dan kelas VIII-C adalah kelas eksperimen.

Teknik pengumpulan data yang dilakukan dalam penelitian ini adalah tes. Tes digunakan Untuk mengukur ada atau tidaknya serta besarnya kemampuan objek yang diteliti. Tehnik pengumpulan data berupa tes digunakan untuk mengukur kemampuan dasar dan pencapaian atau prestasi. Dengan cara tes, akan diketahui berupa kemampuan dari masing-masing siswa. Tes tersebut adalah post test yang dilakukan oleh siswa setelah guru memberikan perlakuan yaitu pembelajaran menulis naskah drama dengan menggunakan model pembelajaran picture and picture dan model pembelajaran konvensional. Tes penugasan adalah suatu cara dengan memberikan tugas yang harus dikerjakan sehingga menghasilkan suatu nilai tingkah laku atau prestasi. Tes penugasan dilakukan dengan pemberian tugas menulis naskah drama berdasarkan model picture and picture. 


\section{HASIL PENELITIAN DAN PEMBAHASAN}

Data dalam penelitian dikumpulkan dengan menggunakan metode eksperimen model posttestonly control design yaitu eksperimen yang menggunakan kelas perbanding. Penelitian ini merupakan penelitian yang melibatkan dua kelas yang diberi perlakuan yang berbeda yaitu kelas eksperimen dan kelas kontrol. Kelas eksperimen menggunakan model picture and picture dan kelas kontrol menggunakan model pembelajaran konvensional dalam hal menulis naskah drama. Setelah dilakukan penelitian terhadap permasalahan yang diambil maka diperoleh data masing-masing kelompok. Kelas eksperimen menggunakan sampel sebayak 30 siswa dan kelas kontrol menggunakan sampel sebanyak 30 siswa.

\section{Tabel 1}

Ukuran Penyebaran Data Post-test kelas kontrol dan Kelas Eksperimen

\begin{tabular}{cc}
\hline Hasil & Mean \\
\hline Kontrol & 75,833 \\
\hline Eksperimen & 82,66 \\
\hline
\end{tabular}

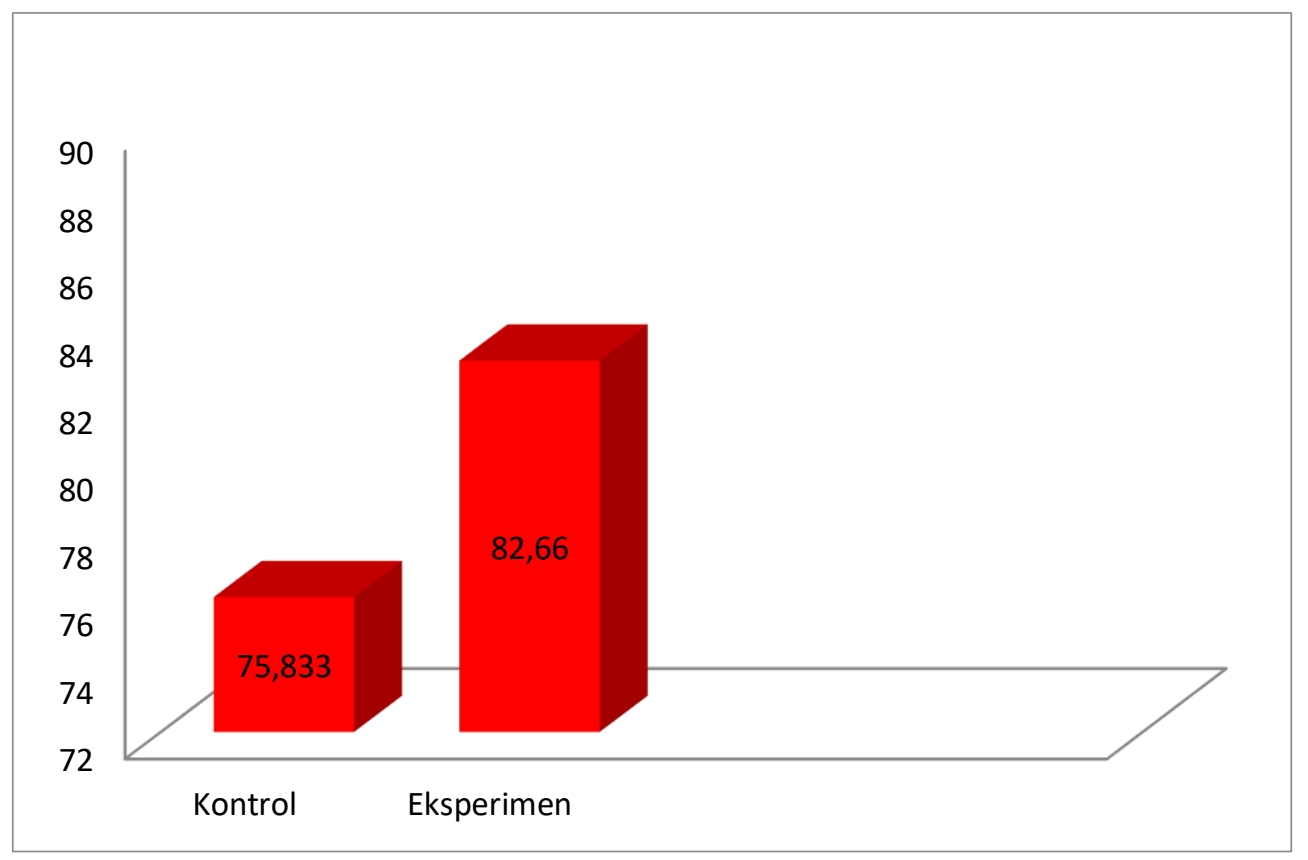

\section{Grafik 1}

Penyebaran Data Kelas Kontrol dan Kelas Eksperimen

Hasil pemberian post-test kepada kelas kontrol dengan jumlah sampel 30 siswa memperoleh nilai rata-rata 75,83 sedangkan untuk kelas eksperimen dengan jumlah sampel 30 siswa memperoleh nilai rata-rata 82,66. Berikut data penelitian dari masing-masing kelompok.

Tabel 4.2 Hasil post-test kelas Kontrol

\section{Hasil post-test kelas Kontrol}




\begin{tabular}{llllll}
\hline No & Nilai & Frekuensi & S & $\mathbf{S}^{2}$ & $\bar{X} \mathbf{i}$ \\
\hline 1 & 50 & 2 & 8,416 & 70,833 & 75,83 \\
\hline 2 & 65 & 1 & & \\
\hline 3 & 70 & 3 & & \\
\hline 4 & 75 & 7 & & \\
\hline 5 & 80 & 14 & & \\
\hline 6 & 85 & 3 & & & \\
\hline
\end{tabular}

Tabel 4.3 Hasil post-test kelas Ekesperimen

Hasil post-test kelas Eksperimen

\begin{tabular}{cccccc}
\hline No & Nilai & Frekuensi & S & $\mathbf{S}^{2}$ & $\bar{X} \mathbf{i}$ \\
\hline 1 & 70 & 3 & 6,914 & $\begin{array}{c}47,8 \\
16\end{array}$ & 82,666 \\
\cline { 1 - 3 } & 75 & 5 & & & \\
\hline 3 & 80 & 5 & & & \\
\hline 4 & 85 & 7 & & & \\
\hline 5 & 90 & 10 & & & \\
\hline
\end{tabular}

Dari hasil perhitungan di atas, maka dapat disimpulkan dikategorikan dalam empat kategori yaitu baik sekali, baik, cukup, kurang (Nurgiyantoro, 2016 :227 ) adapun ketentuan kriteria tersebut dapat dilihat pada tabel berikut

Tabel 4

Identifikasi Kecendrugan Hasil Post-test kelas control

\begin{tabular}{lllll}
\hline No & Nilai & Frekuensi & Persentase & Kategori \\
\hline 1 & $86-100$ & 0 & $0 \%$ & Baik Sekali \\
\hline 2 & $76-85$ & 17 & $57 \%$ & Baik \\
\hline 3 & $56-75$ & 11 & $36 \%$ & Cukup \\
\hline 4 & $10-55$ & 2 & $7 \%$ & Kurang \\
\hline
\end{tabular}

Berdasarkan tabel diatas maka dapat diketahui bahwa kemampuan menulis naskah drama siswa kelas kontrol kategori baik sekali sebanyak 0 siswa kategori baik sebanyak 17 atau 57\% 
kategori cukup sebanyak 11 siswa atau 36\%, dan kategori kurang sebanyak 2 orang siswa atau $7 \%$. Frekuensi tersebut dapat digunakan dalam bentuk grafik berikut ini.

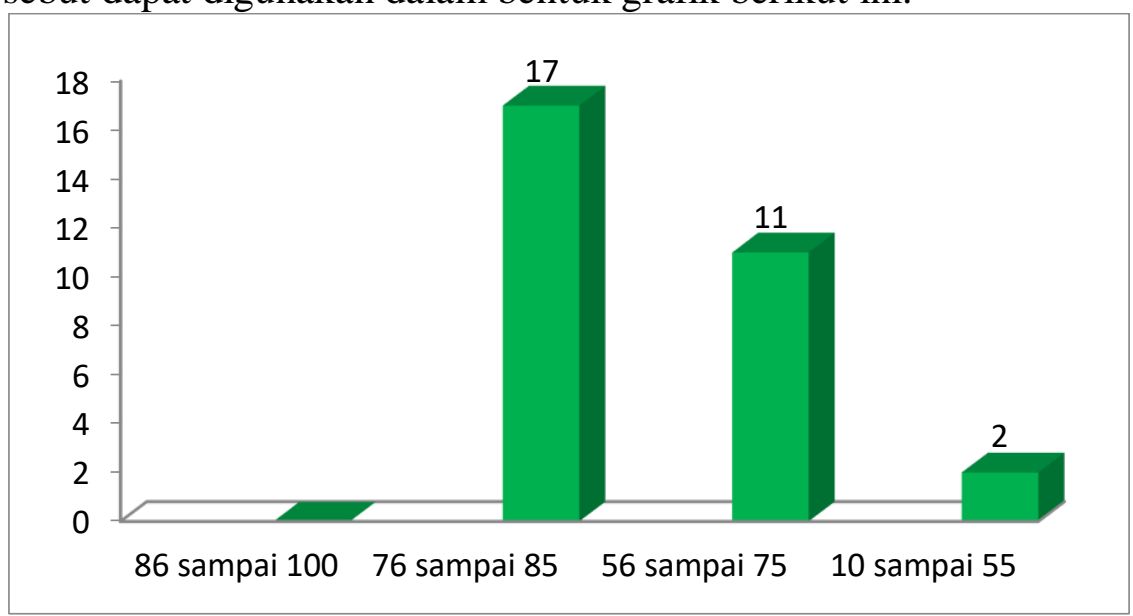

Grafik 2

Post-test kelas kontrol

Tabel 5

Identifikasi Kecendrugan Hasil Post-test kelas Eksperimen

\begin{tabular}{ccccc}
\hline No & Nilai & Frekuensi & Persentase & Kategori \\
\hline 1 & $86-100$ & 10 & $33 \%$ & Baik Sekali \\
\hline 2 & $76-85$ & 12 & $40 \%$ & Baik \\
\hline 3 & $56-75$ & 8 & $27 \%$ & Cukup \\
\hline 4 & $10-55$ & 0 & $0 \%$ & Kurang \\
\hline
\end{tabular}

Berdasarkan tabel diatas maka dapat diketahui bahwa kemampuan menulis naskah drama siswa kelas kontrol kategori baik sekali sebanyak 10 siswa atau 33\% atau kategori baik sebanyak 12 siswa atau $40 \%$ kategori cukup sebanyak 8 siswa atau 27\%, dan kategori kurang sebanyak 2 orang siswa atau $7 \%$. Frekuensi tersebut dapat digunakan dalam bentuk grafik berikut ini. 


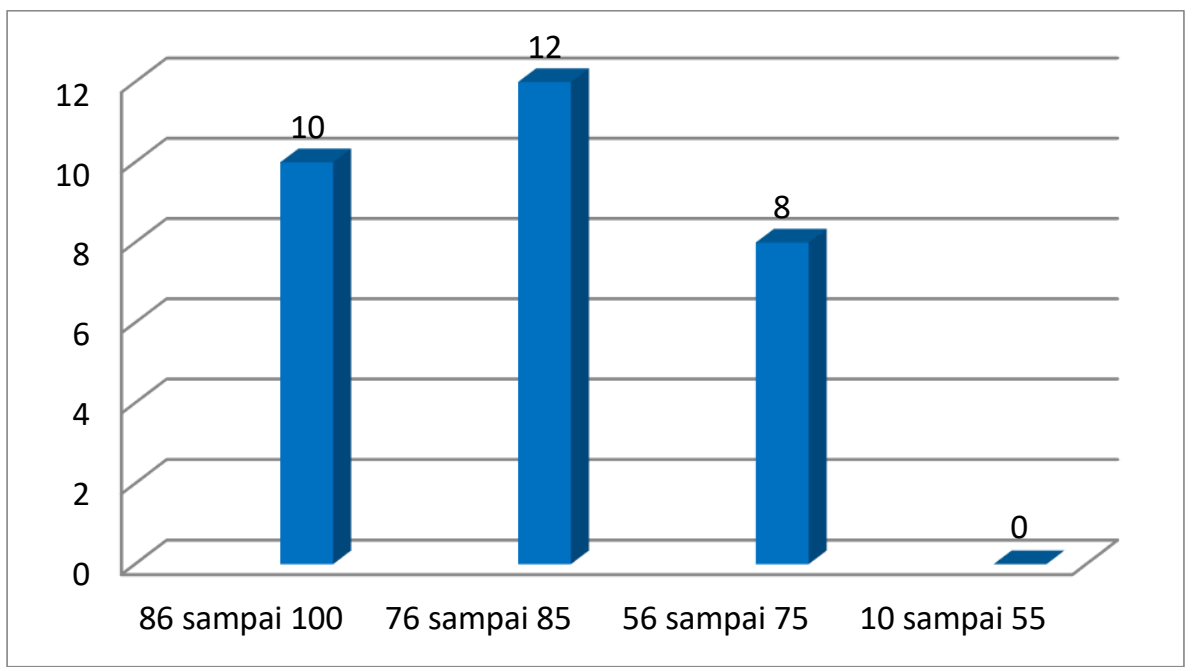

\section{Grafik 4.3 post-test Kelas Eksperimen}

Analisis data dilakukan menggunakan uji statistik deskriptif, dan inferensial dengan syarat data-data yang diuji harus berdistribusi normal dan homogen. Oleh karena itu, pengujian normalitas dilakukan dengan uji liliefors dan uji homogenitas data dengan uji homogenitas varians.

Untuk mengetahui keadaan sampel yang diteliti, maka asumsi dari penelitian merupakan persyaratan analisis yang penting untuk diperiksa. Uji normalitas digunakan untuk mengetahui apakah populasi data berdistribusi normal atau tidak. Untuk menguji normalitas data digunakan uji liliefors.

Tabel 6

Uji Normalitas Menggunakan Model Pembelajaran Konvensional

\begin{tabular}{ccccccc}
\hline $\mathbf{N O}$ & $\mathbf{X i}$ & $\mathbf{F k}$ & $\mathbf{Z i}$ & $\mathbf{F}(\mathbf{Z i})$ & $\mathbf{S}(\mathbf{z i})$ & Lhitung \\
\hline 1 & 50 & 2 & $-3,07$ & 0,0011 & 0,0667 & 0,0656 \\
\hline 2 & 65 & 3 & 1,29 & 0,0985 & 0,1000 & 0,0015 \\
\hline 3 & 70 & 6 & $-0,27$ & 0,2358 & 0,2000 & 0,0358 \\
\hline 4 & 75 & 13 & $-0,09$ & 0,4641 & 0,4333 & 0,0308 \\
\hline 5 & 80 & 27 & 0,49 & 0.7723 & 0,9000 & 0,1277 \\
\hline 6 & 85 & 30 & 1,09 & 0,8679 & 1,0000 & 0,1321 \\
\hline
\end{tabular}

Berdasarkan tabel tersebut diperoleh nilai $\mathrm{L}_{\text {hitung }}$ yang diambil dari nilai $\mathrm{L}_{\text {hitung }}$ yang paling besar diantara selisih, sehingga dari tabel diatas $\mathrm{L}_{\text {hitung }}$ diketahui, selanjutnya dikonsultasikan melalui uji liliefors pada taraf signifikan $\alpha=0,05$ dan $\mathrm{N}=30$, diperoleh $\mathrm{L}_{\text {tabel }}=0,1617$. Dengan demikian dapat disimpulkan bahwa $\mathrm{L}_{\text {hitung }}<\mathrm{L}_{\text {tabel }}$ yaitu $0,1321<0,1617$. Oleh karena itu, data 
kemampuan menulis naskah drama dengan menggunakan model pembelajaran konvensional berdistribusi normal.

Tabel 7

Uji Normalitas Menggunkan Model Pembelajaran Picture And Picture

\begin{tabular}{lllllll}
\hline No & $\mathbf{X i}$ & $\mathbf{F k}$ & $\mathbf{Z i}$ & $\mathbf{F}(\mathbf{Z i})$ & $\mathbf{S}(\mathbf{z i})$ & Lhitung \\
\hline 1 & 70 & 3 & $-1,83$ & 0,336 & 0,1000 & 0,0664 \\
\hline 2 & 75 & 8 & $-1,10$ & 0,1357 & 0,2667 & 0,131 \\
\hline 3 & 80 & 13 & $-0,38$ & 0,352 & 0,4333 & 0,0813 \\
\hline 4 & 85 & 20 & 0,34 & 0,6159 & 0,6667 & 0,0508 \\
\hline 5 & 90 & 30 & 1,06 & 0,8554 & 1,0000 & 0,1446 \\
\hline
\end{tabular}

Berdasarkan tabel tersebut diperoleh nilai $\mathrm{L}_{\text {hitung }}$ yang diambil dari nilai $\mathrm{L}_{\text {hitung }}$ yang paling besar diantara selisih, sehingga dari tabel diatas $\mathrm{L}_{\text {hitung }}$ diketahui, selanjutnya dikonsultasikan melalui uji liliefors pada taraf signifikan $\alpha=0,05$ dan $\mathrm{N}=30$, diperoleh $\mathrm{L}_{\text {tabel }}=0,1617$. Dengan demikian dapat disimpulkan bahwa $\mathrm{L}_{\text {hitung }}<\mathrm{L}_{\text {tabel }}$ yaitu $0,1446<0,1617$. Oleh karena itu, data keampuan menulis naskah drama dengan menggunakan model pembelajaran picture and picture berdistribusi normal.

Uji homogenitas dilakukan untuk mengetahui apakah sampel berasal dari populasi yang homogen atau tidak. Kriteria pengujian homogenitas adalah $\mathrm{H}_{0}$ diterima jika $\mathrm{F}_{\text {hitung }}<\mathrm{F}_{\text {tabel }}$ yang menyatakan bahwa sampel berasal dari populasi yang homogen. Untuk menguji perbedaan hasil belajar perlu dilakukan uji kesaaan dua varians.

\section{Tabel 8}

\section{Uji Homogenitas Data}

\begin{tabular}{|c|c|c|c|c|c|}
\hline No & Data & Varians & $\mathbf{F}_{\text {hitung }}$ & $\mathbf{F}_{\text {tabel }}$ & Kesimpulan \\
\hline 1 & Post-test kontrol & 70,833 & 1,481 & 1,858 & Homogen \\
\hline 2 & Post-test eksperimen & 47,816 & & & \\
\hline
\end{tabular}

Berdasarkan tabel 4.8 di atas, data post-test untuk kedua sampel diperoleh pengujian $\mathrm{F}_{\text {hitung }}$ $<\mathrm{F}_{\text {tabel }}$ maka hal ini membuktikan bahwa sampel memiliki varians yang homogen atau $\mathrm{H}_{0}$ diterima.

Berdasarkan hasil uji normalitas data test terakhir kedua sampel berdistribusi normal dan mempunyai varians yang homogen, maka untuk menguji hipotesis digunakan uji kesamaan rata-rata dengan uji “t”", secara statistik hipotesisnya adalah

$$
\begin{aligned}
& H 0: X 1=X_{2} \\
& H_{a}: X_{1} \neq X_{2}
\end{aligned}
$$


Kriteria pengujiannya adalah $\mathrm{H}_{\mathrm{a}}$ diterima jika $-\mathrm{t}(1-1 / 2 \alpha)<\mathrm{t}_{\text {hitung }}<\mathrm{t}(1-1 / 2 \alpha)$.

\begin{tabular}{cccccc}
\multicolumn{5}{c}{ Tabel 9 } \\
Uji Hipotesis \\
\hline No & Data & Nilai rata-rata & $\mathbf{t}_{\text {hitung }}$ & $\mathbf{t}_{\text {tabel }}$ & Kesimpulan \\
& & & 3,531 & 2,002 & $\begin{array}{c}\text { Ada pengaruh } \\
\text { yang signifikan }\end{array}$ \\
\hline 1 & Post-test & & & \\
& Eksperimen & & & & \\
\hline 2 & Post-test & 75,833 & & & \\
& Kontrol & & & &
\end{tabular}

Berdasarkan perhitungan yang telah dilakukan, maka dapat diketahui bahwa $t_{\text {hitung }}>t_{\text {tabel }}$ yakni 3,531>2,002, sehingga hipotesis nol $\left(\mathrm{H}_{0}\right)$ ditolak dan hipotesis alternative $\left(\mathrm{H}_{\mathrm{a}}\right)$ diterima, dapat disimpulkan bahwa model pembelajran picture and picture memiliki pengaruh terhadap kemampuan menulis naskah drama satu babak siswa kelas VIII SMP Swasta Imelda Medan Tahun Pelajaran 2018/2019.

Hasil penelitian menunjukkan bahwa pengaruh model pembelajaran picture and picture terhadap kemampuan menulis naskah drama lebih baik dibandingkan model pembelajaran konvensional. Hal ini dapat diketahui berdasarkan uji "t" yang dilakukan yaitu menunjukkan perbedaan nyata dengan $t_{\text {hitung }}=3,531>t_{\text {tabel }}=2,002$.

Berdasarkan penelitian yang dilakukan terhadap siswa diperoleh bahwa rata-rata hasil belajar siswa setelah diberi perlakuan dengan pengajaran model pembelajaran picture and picture $=82,77>$ dari rata-rata hasil belajar dengan menggunakan model pembelajaran konvensional $=75,83$ maka besar kontribusi model pembelajaran picture and picture terhadap peningkatan hasil belajar siswa adalah sebesar 8,2675\% dibanding model pembelajaran konvensional.

Pembelajaran dengan menggunakan model picture and picture ini menekankan siswa untuk belajar berfikir kritis dengan memecahkan permasalahan-permasalahan yang termuat dalam gambar yang disajikan. Dalam penggunaan media gambar dirancang agar siswa dapat menganalisis gambar tersebut untuk kemudian dideskripsikan secara singkat perihal isi sebuah gambar.

Dengan pengajaran ini juga siswa mampu memberikan masukan-masukan kepada siswa yang lain sehingga siswa yang kurang mampu menjadi lebih termotivasi untuk mempelajari materi yang kurang dipahami. Dengan tujuan agar siswa saling berbagi kemampuan, saling menyampaikan pendapat, saling memberikan kesempatan mmenyalurkan kemampuan, dan saling membantu belajar.

Hasil penelitian menunjukkan bahwa nilai rata-rata kemampuan menulis naskah drama dengan menggunkan model pembelajaran picture and picture lebih tinggi daripada nilai rata-rata kemampuan menulis naskah drama menggunakan model pembelajaran konvensional. Hal tersebut membuktikan bahwa model picture and picture tepat digunakan untuk pembelajaran menulis naskah drama.

Selain itu, terbukti bahwa model pembelajaran picture and picture memiliki pengaruh yang signifikan terhadap kemampuan menulis naskah drama satu babak siswa kelas VIII SMP Swasta Imelda Medan Tahun Pelajaran 2018/2019. Hal tersebut dibuktikan dengan diberikan perlakuan yang berbeda antara kelas eksperimen dan kelas kontrol.

\section{SIMPULAN}

Berdasarkan hasil analisis data dan uji statistik pada bab IV ditetapkan kesimpulan sebagai berikut: Kemampuan menulis naskah drama dengan menggunakan model pembelajaran konvensional diperoleh mean (rata-rata) 75,83 termasuk dalam kategori cukup (B). Dapat diketahui bahwa 
kemampuan menulis naskah drama siswa termasuk kategori baik sekali sebanyak 0 siswa atau $0 \%$, baik sebanyak 17 siswa atau 57\%, kategori cukup sebanyak 11 siswa atau 36\%, kurang sebanyak 2 siswa atau $7 \%$.

Kemampuan menulis cerita fabel menggunakan model pembelajaran inkuiri diperoleh mean (rata-rata) 82,66 termasuk dalam kategori baik (B). Dapat diketahui bahwa Kemampuan menulis naskah drama siswa termasuk kategori baik sekali sebanyak 10 siswa atau 33\%, baik sebanyak 12 siswa atau $40 \%$, kategori cukup sebanyak 8 siswa atau 27\%, kurang sebanyak 0 siswa atau $0 \%$.

Berdasarkan perhitungan yang telah dilakukan. Maka dapat diketahui bahwa $t_{\text {hitung }}>t_{\text {tabel }}$ yakni 3,531 > 2,002. Dengan demikian, hipotesis nihil $\left(\mathrm{H}_{\mathrm{o}}\right)$ ditolak dan hipotesis alternatif $\left(\mathrm{H}_{\mathrm{a}}\right)$ diterima. Berdasarkan data tersebut, maka dapat disimpulkan bahwa Model Pembelajaran picture and picture memiliki pengaruh terhadap kemampuan menulis naskah drama pada siswa kelas VIII SMP Imelda Medan Tahun Pembelajaran 2018/2019.

\section{DAFTAR PUSTAKA}

Addin. (2009). Menulis Naskah Drama. Bandung :Putri Delco.

Addin. (2009). Belajar Seni Drama. Bandung :Puri Pustaka.

Arikunto. S. (2017). Prosedur Penelitian Suatu Pendekatan Praktik. Jakarta: Rineka Cipta.

Dalman. (2012). Keterampilan Menulis. Jakarta: Raja Grafindo Persada

Huda, Miftahul. 2013. Model-Model Pengajaran dan Pengembangan. Malang: Pustaka Belajar.

Fathurrohman. (2018). Mengenal lebih dekat pendekatan dan model pembelajaran. Yogyakarta: Kalimedia.

Sugiyono. (2017). Metode penelitian pendidikan pendekatan kuantitatif, kualitatif, dan $R \& D$. Bandung: alfabeta.

Shoimin. A.(2016). 68 Model Pembelajaran Inovatif Dalam kurikulum 2013. Yogyakarta: Ar-Ruzz Media. 